\section{THE STRUCTURE OF STENDOMYGIDINE}

Sir :

In an earlier communication ${ }^{1)}$ a basic amino acid constituent of the antifungal peptide antibiotic stendomycin ${ }^{2)}$ was already briefly mentioned as an $\mathrm{N}, \mathrm{N}^{\prime}$-dimethyl derivative of 2-imino-hexahydro-4-pyrimidyl-glycine and hence related to capreomycidine, a basic amino acid from capreomycin $^{3)}$. In this communication the name "stendomycidine" and structure I are proposed for the basic amino acid from stendomycin.<smiles>CC1=C(C)N(C)CCCN1</smiles>

(1)

A sample of the antibiotic was hydrolyzed with constant boiling hydrochloric acid under reflux in an atmosphere of nitrogen for 60 hours. After removal of the fatty acids ${ }^{4}$ by extraction with hexane and evaporation to dryness, the residual mixture of amino acid hydrochlorides was chromatographed on an ion-exchange column (Dowex $50 \mathrm{~W}-\mathrm{X} 124.5 \mathrm{~cm} \times 40.6 \mathrm{~cm}$, in $\mathrm{H}^{+}$cycle). For elution hydrochloric acid, in gradually increasing concentration, was used. Stendomycidine emerged near the end of the elution procedure, when the concentration of the hydrochloric acid was raised to $6 \mathrm{~N}$. The material thus separated was still somewhat contaminated with alloisoleucine. Final purification was achieved by countercurrent distribution (30 transfers) in a system of $n$ butanol-0.001 N HCl $(1: 1)$. The dihydrochloride was secured by evaporation of the solvents from the contents of tubes No. $0 \sim 5$ as a crystalline, but somewhat hygroscopic material. On paper chromatograms and thin-layer chromatograms developed with butanol-acetic acid-water $(3: 1: 1)$ it gave a single ninhydrin-positive spot $(\mathrm{Rf}=0.2)$.

Calc'd for $\mathrm{C}_{8} \mathrm{H}_{16} \mathrm{~N}_{4} \mathrm{O}_{2} \cdot 2 \mathrm{HCl}$ : C $35.2, \mathrm{H} 6.6, \mathrm{~N} 20.5, \mathrm{Cl} 26.0$

Found: C 34.9, H 6.9, N 20.3, Cl 26.1
Addition of a solution of flavianic acid in water to an aqueous solution of the dihydrochloride converted it to the sparingly soluble diflavianate, which crystallized in well formed plates.

Calc'd for $\mathrm{C}_{28} \mathrm{H}_{28} \mathrm{~N}_{8} \mathrm{O}_{18} \mathrm{~S}_{2}$ :

C $40.6, \mathrm{H} 3.4, \mathrm{~N} 13.5, \mathrm{~S} 7.7$

Found: C 40.3, H 3.6, N 13.7, S 7.7

Subsequently it was found that stendomycidine diflavianate can be isolated in pure form directly from the mixture of amino acid hydrochlorides (after the removal of the fatty acids and hydrochloric acid) by the addition of excess flavianic acid to their aqueous solution.

While stendomycidine gives a strong reaction with ninhydrin, treatment with nitrous acid yielded a ninhydrin-negative product. Strong alkalies liberated methylamine; the same amine appeared also on prolonged treatment of stendomycidine with ammonia*. From these observations, from the values of elemental analysis including $\mathrm{N}$-methyl determinations and mainly from the NMR spectrum (Fig. 1) structure I could be proposed for stendomycidine.

The position of the $\mathrm{N}$-methyl groups could be assigned as shown on Fig. 1 through exclusion of the $\alpha$-amino group (ninhydrin reaction, positive before and negative after deamination) and by the chemical shifts (3.89 ppm with external TMS as standard) of the protons on the $\delta$-carbon. This value was found to be identical with the one determined on a sample of capreomycidine ${ }^{3)}$ received from the Lilly Research Laboratories. Observations made on model compounds show that the chemical shift of protons on a carbon next to a nitrogen atom is changed to lower $\delta$ values when a hydrogen on the nitrogen atom is substituted by a methyl group. Therefore, in stendomycidine no methyl group is present on the nitrogen adjacent to the $\delta$-carbon.

Stendomycidine, while probably derived biogenetically from arginine, has two centers of asymmetry. According to the CloughLutZ-JiRgENSONS rule $^{5 \text { ) }}$ the $\alpha$-carbon atom has the L-configuration; this was supported by the ORD spectrum $^{6)}$ of the copper complex of stendomycidine.

Determination of the configuration of the $\beta$-carbon atom is more complex. The

* The exchange of $\mathrm{CH}_{3}-\mathrm{N}=$ with $\mathrm{NH}=$ on the action of ammonia was observed by Dr. IcHIRO Muramatsu, presently in this laboratory. 
Fig. 1. NMR spectra (100 Mc)

(a) Capreomycidine dihydrochloride and (b) stendomycidine dihydrochloride in $\mathrm{D}_{2} \mathrm{O}$ (external TMS as standard).

(a)
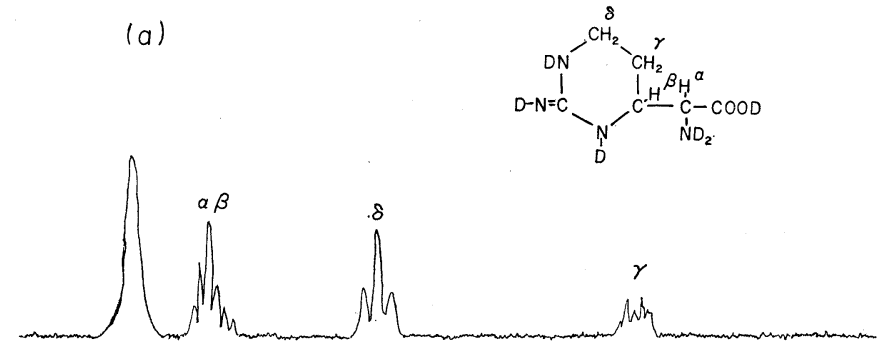

(b)

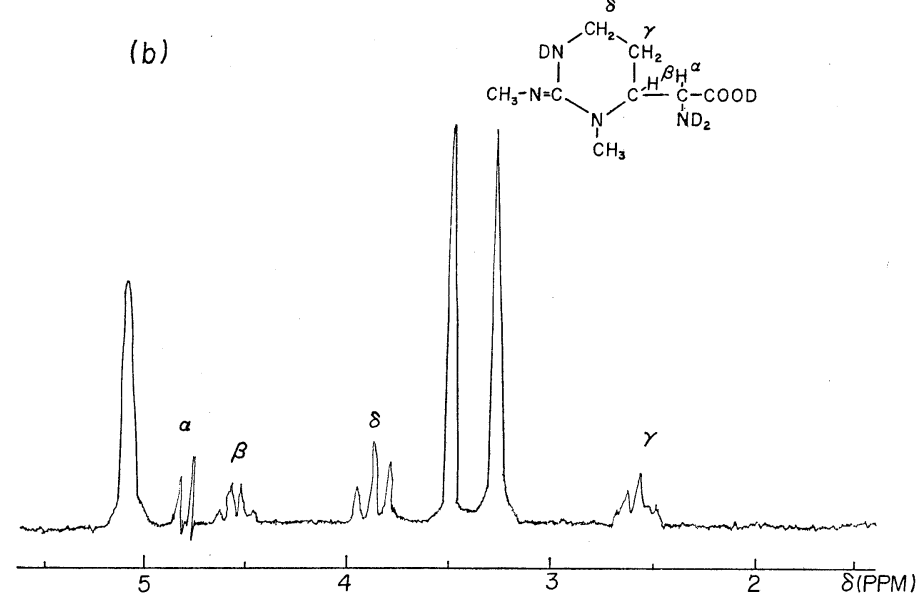

Miklos Bodanszky GARY G. MARCONI

Agnes Bodanszky

Department of Chemistry

Case Western Reserve

University

Cleveland, Ohio 44106, U.S.A.

(Received November 21, 1968)

\section{References}

1) Bodanszky, M.; I. Muramatsu, A. Bodanszky, M. Lukin \& M. R. Doubler: Amino acid constituents of stendomycin. J. Antibiotics $21: 77 \sim 78,1968$.

2) Thompson, R. Q. \& M. S. Hughes: Stendomycin. A new antifungal antibiotic. J. Antibiotics, Ser. A 16 : $187 \sim 194,1963$.

3) Herr, E. B., Jr.: Chemical and biological properties of capreomycin and other peptide antibiotics. Antimicr. Agents \& Chemoth. 1962 : 201 212, 1963.

4) Bodanszky, M.; I. MuraMATSU \& A. BoDANSZKY: Fatty acid constituents of the antifungal antibiotic stendomycin. J. Antibiotics, Ser. A $20: 384 \sim 385$, 1967. chemical shift at this center is influenced not only by the relative configuration of the $\alpha$ - and $\beta$-carbon atoms, but also by the methyl group on the nitrogen adjoining the $\beta$ carbon. On the other hand, the protons on the $\gamma$ - and $\delta$-carbon atoms appear at $2.56 \mathrm{ppm}$ and $3.89 \mathrm{ppm}$, respectively, both in stendomycidine and in capreomycidine (cf. Fig. 1). The chemical shifts of the protons on the $\delta$-carbon should be independent of the configuration at the $\beta$-carbon and also from the presence or absence of a methyl group on the nitrogen adjacent to the $\beta$-carbon. The chemical shift on the $\gamma$-carbon, however, is a function** of the stereochemistry at the $\beta$-center. Hence, the relative stereochemistry at the $\beta$ - and $\alpha$-carbons in stendomycidine should be the same as in capreomycidine ${ }^{* * *}$.
5) Clough, G. W.: The relationship between the optical rotatory power and relative configurations of optically active compounds. J. Chem. Soc. 113: 526 554, 1918.

Lutz, O. \& B. Jiraensons: Über eine neue Methode der Zuteilung optisch-activer $\alpha$-Aminosäuren zur Rechts-oder Linksreihe. I. Ber. $63: 448 \sim 460,1930$.

Lutz, O. \& B. Jirgensons: Über eine neue Methode der Zuteilung optisch-activer $\alpha$-Aminosäuren zur Rechts-oder Linksreihe. II. Ber. $64: 1221 \sim 1232,1931$.

6) Izumiya, N.; M. Winitz, S. M. Birnbaum \& J. P. Greenstein: Studies on Diastereoisomeric $\alpha$-amino acids and corresponding $\alpha$ hydroxy acid. VI. Rotatory dispersion of copper complexes. J. Am. Chem. Soc. 78 : $1602 \sim 1605,1956$.

Pfeiffer, P. \& W. Christeleit: Komplexchemische Methode zur relativen Konfigurationsbestimmung der natürlichen $\alpha$ Aminosäuren. Zeit. Physiol. Chem. 245 : $197 \sim 202,1937$.

** The influence of the relative stereochemistry at the $\alpha$ - and $\beta$-carbons of diasymmetric amino acids on the chemical shifts of protons on the $\gamma$-carbon is shown in threonine and allothreonine (1.33 ppm and $1.28 \mathrm{ppm}$, respectively, in $\mathrm{D}_{2} \mathrm{O}$ with $1 \% \mathrm{DSS}$ as standard).

*** According to T. Takita \& K. Maeda (J. Antibiotics, Ser. A $21: 512 \sim 516$, 1968), dihydroviomycidine is the diastereomer of capreomycidine. Their NMR spectra are different. The absolute chirality of capreomycidine has been established by B. W. Bycroft and his associates at the University of Nottingham, England (personal communication from Dr. ByCROFT). 